\title{
Multigene panel testing for hereditary breast cancer: An analysis of 70 BRCA-negative turkish patients
}

\section{Herediter meme kanserinde çoklu gen paneli uygulaması: 70 BRCA-negatif türk hastanın analizi}

\author{
Haktan Bağıș Erdem, Taha Bahsi
}

University of Health Sciences, Dr. Abdurrahman Yurtaslan Ankara Oncology Training and Research Hospital, Department of Medical Genetics,
Ankara, Turkey
Corresponding author: Haktan Bağı̧ Erdem, MD, University of Health Sciences, Dr. Abdurrahman Yurtaslan Ankara Oncology Training and
Research Hospital, Department of Medical Genetics, Ankara, Turkey
E-mail: haktanbagis@atauni.edu.tr
Received/Accepted: July 23,2019/September 27,2019

\section{SUMMARY}

Objective: Although the molecular etiology of breast cancer is not clearly known, hereditary genetic causes are responsible for approximately $10 \%$. In addition to BRCA1 and BRCA2 genes, there are many genes that cause breast cancer. In this study, we performed a hereditary cancer genetic panel test among hereditary breast cancer patients who are negative for BRCA1 and BRCA2 genes. Accordingly, the frequency of mutations, causing hereditary cancer among Turkish breast cancer patients, was investigated. Method: All the 70 patients were unrelated and provided BRCA testing criteria according to the National Comprehensive Cancer Network guidelines, but they were reported as unfavorable. Qiagen large hereditary cancer panel and Hereditary Cancer Solution v1.1 panel were used for sequencing. The sequencing process was performed on the Illumina MiSeq system. The data analyses were performed on QIAGEN Clinical Insight $\left(\mathrm{QCI}^{\mathrm{TM}}\right)$ Analyze software and Sophia DDM software.

Results: Of 70 patients, $6(8.5 \%)$ were found to carry a pathogenic, and 1 $(1.4 \%)$ were found to give a likely pathogenic mutation. Pathogenic variants were detected in ATM, NBN, PTEN, RAD51C genes; the likely pathogenic variant was discovered in the MUTYH gene. Only, PTEN:c.407G>A mutation was found in two patients; the other mutations were detected once in each patient. A nonsense alteration, RAD51C:c.907G $>$ T, was described as a novel variant. The variant of uncertain significance variants was detected in 10 patients $(14.2 \%)$.

Conclusions: It is essential to perform the hereditary cancer panel from index cases in families with high cancer incidence, whose BRCA1/2 negative and molecular background has not been elucidated, for preventive health policies. In addition, the identification of common familial cancer genes will guide personalized therapy planning.

Keywords: Breast cancer, hereditary cancer panel, BRCA1, BRCA2
Haktan Bağış Erdem

Taha Bahsi

ORCID IDs of the authors:

H.B.E. 0000-0002-4391-1387

T.B. 0000-0001-7210-7374 
Amaç: Meme kanserinin moleküler etyolojisi tam olarak aydınlatılamamış olsa da, yaklaşık \%10'unun kalıtımsal genetik sebeplerle oluştuğu bilinmektedir. BRCA1 ve BRCA2 genlerine ek olarak meme kanserine sebep olan birçok gen tanımlanmıştır. Bu çalışmada, BRCA1 ve BRCA2 genleri açısından negatif çıkan ailesel meme kanseri hastalarına, ailesel kanser genetik paneli çalışılmıştır. Bu doğrultuda, Türk meme kanseri hastalarında, ailesel kansere sebep olan genlerin s1klı̆̆ araștırılmıștır.

Yöntem: Çalışmamızdaki 70 hastanın hepsi, akraba olmayan ve Amerikan Ulusal Kanser Ağı'nın BRCA testine alınacak hastalar için belirlediği kriterlere göre çalışlıp, BRCA negatif çıkmış hastalardan seçilmiştir. Qiagen geniş kanser paneli ve Hereditary Cancer Solution v1.1 paneli dizilemede kullanılmıştır. Dizileme işlemi llumina MiSeq yeni nesil dizileme sisteminde gerçekleştirilmiştir. Data analizi için QIAGEN Clinical Insight (QCITM) ve Sophia DDM programları kullanılmıștır.

Bulgular: 70 hastanın 6'sında (\%8.5) patojenik, 1'inde (\%1.4) olası patojenik mutasyon tespit edilmiştir. Patojenik varyantlar ATM, NBN, PTEN, RAD51C genlerinde, olası patojenik varyant ise MUTYH geninde tespit edildi. Sadece PTEN:c.407G>A mutasyonu iki hastada birden tespit edildi, diğer mutasyonlar birer kez tespit edildi. RAD51C:c.907G>T nonsense varyantı daha önce bildirilmemiş varyant olarak tanımlandı. 10 hastada (\%14.2) önemi bilinmeyen genomik değişiklik tespit edildi.

Sonuç: Kanser görülme oranının yüksek olduğu, BRCA1/2 genleri normal bulunmuş ve moleküler arka planı tam olarak aydınlatılamamış ailelerde, indeks vakaya ailesel kanser paneli çalışılması, koruyucu-önleyici sağlık politikaları geliştirilmesi için önem arz etmektedir. Buna ek olarak, sık görülen ailesel kanser genlerinin tanımlanması kişiye özel tedavi planlamasında da yol gösterici olacaktır.

Anahtar sözcükler: Meme kanseri, ailesel kanser paneli, BRCA1, BRCA2

\section{INTRODUCTION}

Breast cancer is the most common type of cancer in females all over the World '. Although the molecular etiology of breast cancer is not clearly known, hereditary genetic causes are responsible for approximately $10 \%{ }^{2,3}$. As with all cancers, breast cancer is a genetic disease, and many genes play a role in the molecular pathogenesis of breast cancer. Tasked with cell cycle checkpoints and DNA repair the trigger of breast cancer is the accumulation of mutations in genes withdrawn. Especially pathogenic mutations in BRCA1 and BRCA2 genes are the most critical genetic causes known for hereditary breast cancer ${ }^{4,5}$. In addition to BRCA1 and BRCA2 genes, there are many genes that cause breast cancer. ATM, CDH1, CHEK2, PALB2, PTEN, STK11, TP53 are important ones. These genes are involved in regulating homologous recombination. It also acts as tumor suppressor genes in DNA repair and is inherited as autosomal dominant or rarely autosomal recessive for example MUTYH gene. Many studies have shown that these genes are responsible for $2-5 \%$ of hereditary breast cancers ${ }^{6}$.

In recent years, next-generation sequencing technologies have become widespread and costeffective, making it easier to investigate mutations in both BRCA1/BRCA2 and other genes known to be responsible for breast cancer. Evaluation of hereditary breast cancer susceptibility genes in individuals enables early identification of individuals at risk and early prevention, especially the choice of preventive surgery. In addition, the importance of genetic testing in the treatment of pharmaceutical agents such as olaparib increases in recent years ${ }^{7}$. The National Comprehensive Cancer Network (NCCN) has published a guide on who should analyze for BRCA1/BRCA2, but there is no precise algorithm and guide for other genes yet ${ }^{8}$. There are not also enough studies on the frequency of mutations of genes in hereditary cancer panel in the Turkish population.

In this study, we performed hereditary cancer genetic panel test among hereditary breast cancer patients who had been performed BRCA1/BRCA2 sequence and multiplex ligation-dependent probe amplification (MLPA) analysis but no unsignificant, or pathogenic variant was detected. The frequency of mutations causing hereditary cancer among Turkish breast cancer patients other than BRCA1/2 genes was investigated.

\section{MATERIAL AND METHODS}

\section{Patients and samples}

Totaly, 70 subjects were performed at the University of Health Sciences, Dr. Abdurrahman Yurtaslan Ankara Oncology Training and Research Hospital, Medical Genetics Clinic, between 2017 and 2019. Written informed consent was obtained from all patients before testing for the use of their DNA samples for research purposes. All the patients were unrelated and provided BRCA testing criteria according to the National Comprehensive Cancer Network (NCCN) guidelines, but they were reported as negative in both next-generation sequencing and MLPA tests. 


\section{Genetic testing}

Blood samples were collected into EDTA tubes. DNA of patients extracted by QIAcube ${ }^{\circledR}$ automated DNA isolation system (Qiagen Inc. Mississauga, ON, Canada). Isolated DNA samples were stored at $-20{ }^{\circ} \mathrm{C}$.

Qiagen large hereditary cancer panel (Qiagen, Hilden, Germany) and Hereditary Cancer Solution v1.1 panel (Sophia Genetics, Saint-Sulp) were used for sequencing. The sequencing process was performed on the Illumina MiSeq system (Illumina
Inc., San Diego, CA, USA). The data analyses were performed on QIAGEN Clinical Insight (QCITM) Analyze software (QIAGEN, Hilden, Germany) for Qiagen large hereditary cancer panel and Sophia DDM software (Sophia Genetics, SaintSulp) for Hereditary Cancer Solution v1.1 panel. The gene content of these hereditary cancer panels was listed in Table 1. Sanger validation was performed for; homopolymer regions, low-quality variants, insertions and/or deletions, splice site alterations and novel variants.

Table 1: Gene content of hereditary cancer panels

\begin{tabular}{|c|c|}
\hline $\begin{array}{c}\text { QIAGEN QIASEQ } \\
\text { HEREDITARY CUSTOM CANCER PANEL }\end{array}$ & $\begin{array}{c}\text { SOPHIA } \\
\text { HEREDITARY CANCER SOLUTION } \\
\text { PANEL }\end{array}$ \\
\hline $\begin{array}{l}\text { AIP, APC, ATM, ATR, AXIN2, BAP1, BARD1, BLM, } \\
\text { BMPR1A, BRCA1, BRCA2, BRIP1, BUB1B, CDH1, } \\
\text { CDK4, CDKN2A, CHEK2, CTNNA1, EPCAM, } \\
\text { FAM175A, FANCC, FLCN } \\
\text { GALNT12,GEN1,GPC3,GREM1, HOXB13, MET, } \\
\text { MLH1, MRE11A, MSH2, MSH6, MUTYH, NBN, } \\
\text { NTHL1, PALB2, PALLD, PIK3CA, PMS1, PMS2, } \\
\text { POLD1, PRSS1, PTCH1, PTEN, RAD50, RAD51B, } \\
\text { RAD51C, RAD51D, RET, RINT1, SDHB, SDHC, } \\
\text { SDHD, SMAD4, SMARCA4, STK11, TP53, VHL, } \\
\text { XRCC2 }\end{array}$ & $\begin{array}{l}\text { ATM, APC, BARD1, BRCA1, BRCA2, } \\
\text { BRIP1, CDH1, CHEK2, EPCAM, FAM175A, } \\
\text { MLH1, MRE11A, MSH2, MSH6, MUTYH, } \\
\text { NBN, PALB2, PIK3CA, PMS2, PMS2CL, } \\
\text { PTEN, RAD50, RAD51C, RAD51D, STK11, } \\
\text { TP53, XRCC2 }\end{array}$ \\
\hline
\end{tabular}

\section{Variant classification}

The recent ACMG/AMP guidelines for standardized variant interpretation in Mendelian disorders was used for classification. Pathogenic variants are well-established, cancer-related DNA changes in the inhouse database and/or in the literature. The main evaluation criteria are represented by robust clinical findings and family history, independent confirmatory observations, and supporting pathogenicity functional studies. Possible pathogenic variants are considered the probable cause of the disease or the effect on the protein function is predicted to be likely deleterious ( $>90 \%$ probability of causing the disease). Variant of uncertain significance (VUS) alterations are genetic variants with unknown or questionable impact on the condition. These variants are typically sporadic and predicted to be deleterious.

\section{RESULTS}

Of 70 patients, $6(8.5 \%)$ were found to carry a pathogenic, and $1(1.4 \%)$ were found to give a likely pathogenic mutation.
Pathogenic variants were detected in ATM, NBN, PTEN, RAD51C genes; the likely pathogenic variant was discovered in the MUTYH gene. Only, PTEN:c.407G $>$ A mutation was found in two patients; the other mutations were detected once in each patient. A nonsense alteration, RAD51C:c.907G $>$ T, was described as a novel variant, according to ClinVar, Human genome mutation database (HGMD) and current literature. VUS alteration was detected in 10 patients (14.2\%).

The spectrum of pathogenic and likely pathogenic mutations comprises $4(57.2 \%)$ nonsense variants, $3(42.8 \%)$ missense variants. The spectrum of VUS variants comprises $7(70 \%)$ missense variants, 1 (10\%) small in-frame deletions/insertions, 1 (10\%) splice site alteration, $1(10 \%)$ start loss. All the pathogenic, likely pathogenic and VUS variants are listed in Table 2. 
Table 2: Described variants from the study group

\begin{tabular}{|c|c|c|c|c|c|c|c|c|c|}
\hline $\mathbf{n}$ & Gene & Transcript ID & Location & cDNA change & $\begin{array}{l}\text { Protein } \\
\text { Change }\end{array}$ & dbSNP & HGMD & Consequence & Variant type \\
\hline 1 & ATM & NM_000051.3 & Intron 14 & c. $2251-4 A>G$ & - & rs786202935 & - & Splice effect & VUS \\
\hline 1 & ATM & NM_000051.3 & Exon 16 & c. $2413 \mathrm{C}>\mathrm{T}$ & p.Arg805Ter & rs780619951 & CM960099 & Nonsense & Pathogenic \\
\hline 1 & ATM & NM_000051.3 & Exon 47 & c. $6860 \mathrm{G}>\mathrm{A}$ & p.Gly2287Glu & rs1800061 & CM1710974 & Missense & VUS \\
\hline 1 & ATM & NM_000051.3 & Exon 50 & c. $7449 \mathrm{G}>\mathrm{A}$ & p.Trp2483Ter & rs773516672 & CM980148 & Nonsense & Pathogenic \\
\hline 1 & ATM & NM_000051.3 & Exon 54 & c.7989_7991delTGT & p.Val2664del & rs876660743 & CD991614 & In frame & VUS \\
\hline 1 & ATM & NM_000051.3 & Exon 62 & c. $8959 \mathrm{G}>\mathrm{T}$ & p.Asp2987Tyr & rs863224582 & - & Missense & VUS \\
\hline 1 & BRIP1 & NM_032043.2 & Exon 20 & c. $3503 \mathrm{~A}>\mathrm{C}$ & p.Lys1168Thr & rs749589266 & - & Missense & VUS \\
\hline 1 & CHEK2 & NM_001005735.1 & Exon 12 & c. $1348 \mathrm{G}>\mathrm{A}$ & p.Ala450Thr & - & - & Missense & VUS \\
\hline 1 & MUTYH & NM_001128425.1 & Exon 10 & c. $884 \mathrm{C}>\mathrm{T}$ & p.Pro295Leu & rs374950566 & CM064129 & Missense & L. pathogenic \\
\hline 1 & NBN & NM_002485.4 & Exon 11 & c. $1474 \mathrm{C}>\mathrm{T}$ & p.Gln492Ter & rs587782130 & CM1717146 & Nonsense & Pathogenic \\
\hline 1 & PALB2 & NM_024675.3 & Exon 04 & c.833_834delTAinsAT & p.Leu278His & rs587778582 & - & Missense & VUS \\
\hline 2 & PTEN & NM_000314.7 & Exon 05 & c. $407 \mathrm{G}>\mathrm{A}$ & p.Cys136Tyr & rs786204859 & CM983501 & Missense & Pathogenic \\
\hline 1 & RAD51B & NM_133509.3 & Exon 02 & c. $2 \mathrm{~T}>\mathrm{C}$ & p.Met1Thr & - & - & Start loss & VUS \\
\hline 1 & RAD51B & NM_133509.3 & Exon 03 & c. $197 \mathrm{C}>\mathrm{T}$ & p.Thr66Met & rs577027561 & - & Missense & VUS \\
\hline 1 & RAD51C & NM_058216.3 & Exon 07 & c. $907 \mathrm{G}>\mathrm{T}$ & p.Glu303Ter & - & - & Nonsense & Pathogenic \\
\hline 1 & SDHC & NM_003001.3 & Exon 06 & c. $424 \mathrm{G}>\mathrm{A}$ & p.Gly142Ser & - & - & Missense & VUS \\
\hline
\end{tabular}




\section{DISCUSSION}

Although BRCA1/2 analysis is recommended as the first step in the diagnosis of hereditary breast cancer, BRCA1/2 mutations are identified in only $25 \%$ of patients ${ }^{9}$. Therefore, multiple gene panels have been optimized to identify patients who cannot be diagnosed with a molecular diagnosis. Hereditary cancer panels have also been used in routine diagnosis due to the increasing availability of next-generation sequencing technology and the reduction in costs. Although there are no radical recommendations, such as prophylactic surgery, for many of the cancer susceptibility genes other than BRCA1/2, these genes also have high protective and preventive value.

With two pathogenic and four VUS changes, the most reported gene in our study was ATM. Homozygous mutations in ATM gene cause ataxiatelangiectasia, cerebellar ataxia associated immunodeficiency syndrome ${ }^{10}$, while heterozygous mutations predispose to pancreatic and prostate cancer, particularly in women with breast cancer. Life-long breast cancer risk is up to $25 \%$ in women with pathogenic heterozygous ATM mutations ${ }^{11}$. Both pathogenic variants of ATM are a nonsense alteration. 19.2\% (180/937) of all reported disease-causing variants are nonsense alterations. ATM:c.2413C $>$ T variation also leads to a considerable splice site alteration, was published with pancreatic ductal adenocarcinoma, in addition to breast cancer ${ }^{12,13}$. ATM:c.7449G $>$ A creates a nonsense variant, which changes a Tryptophan to a premature stop codon (TGG>TGA); however, it has been also demonstrated that ATM:c.7449G $>$ A creates a cryptic splice donor site resulting in a deletion of the last 70 nucleotides of exon 50, previously referred to as exon 52. This variation is suggested to be a founder mutation in the Costa Rican population ${ }^{14,15}$. Since there is no study on ATM founder mutations in Turkish society, it is not known whether this variant has a founder effect in the Turkish population. The only splice site alteration, ATM: c. 2251-4A $>\mathrm{G}$, has no significant splicing motif alteration, according to Human Splicing Finder (http://www.umd.be/HSF/). Two missense variations were reported as VUS. This variant has been published in an individual with colorectal cancer ${ }^{16}$. ATM Gly2287Glu was not observed at a significant allele frequency in large population cohorts. This variant is located in the FAT domain ${ }^{17}$. In silico analysis, which includes protein predictors and evolutionary conservation, supports that this variant does not alter protein structure/function. One inframe deletion
ATM:c.7989_7991delTGT, described as uncertain genomic alteration, previously ${ }^{18}$.

Although the loss of function mutations of the BRIP1 gene is mostly associated with ovarian cancer risk, the risk ratio is not reported but also increases breast cancer susceptibility ${ }^{19}$. Only reported variant in BRIP1 gene, BRIP1:c.3503A $>\mathrm{C}$ was classified as VUS. The mutated protein region is weakly conserved, and there is a moderate physicochemical difference between lysine and threonine. This variant is present in population databases (rs749589266, ExAC $0.002 \%)$. ClinVar contains two entries for this variant (Variation ID: 439028) as uncertain significance. Algorithms developed to predict the effect of missense changes on protein structure and function (SIFT, PolyPhen-2, Align-GVGD) all suggest that this variant is likely to be tolerated, but these predictions have not been confirmed by published functional studies, and their clinical significance is uncertain.

Truncating mutations in the CHEK2 gene predispose to breast cancer ${ }^{20}$. In our study, CHEK2 variation was reported in a single patient. Although this variation is not seen in the healthy population, it has been reported as VUS because of a change in missense and no truncating effect.

Biallelic MUTYH gene mutations predispose to breast cancer, but it is controversial that monoallelic MUYH mutations increase breast cancer ${ }^{21}$. In our study, only one patient had a missense likely pathogenic heterozygous MUTYH mutation (MUTYH:c.884C > T). Due to the second hit missing, the possible pathogenic change detected in this patient was not associated with the clinic.

The NBN gene, along with MRE11A and RAD50 genes, repairs the DNA damage by forming the MRN complex. Mutations of NBN gene lead Nijmegen breakage syndrome, a condition that causes slow growth in infancy and early childhood ${ }^{22}$. Of the three genes in the MRN complex, NBN mutation has the most substantial relationship with breast cancer ${ }^{23}$. Heterozygous mutations of the NBN gene may also show susceptibility to cancer ${ }^{24}$. Pathogenic reported NBN variant, NBN:c.1474C $>\mathrm{T}$ has been previously reported pathogenically by many centers, and has a truncating effect. The results obtained from this study confirmed that heterozygous mutations of the NBN gene increased the risk of cancer.

For female PALB2 mutation carriers, the average risk of breast cancer until the age of 70 was $35 \%{ }^{25}$. The VUS variant detected in our study, 
PALB2:c.833_834delTAinsAT (p.Leu278His), was identified in $2 \%$ healthy Central Asian individuals undergoing whole-genome sequencing 26; of note, since the genome data of the Turkish population has not been established yet, this data could not be confirmed in the Turkish people. This variant is located within a region of interaction with BRCA1 ${ }^{27}$. In silico analysis supports that this variant does not have an impact on protein function.

PTEN mutations are diagnostic for PTEN hamartoma tumor syndrome (PHTS). There are several syndromes associated with PHTS, such as Cowden syndrome. It has been reported that lifetime risk of breast cancer increases by up to $50 \%$ in PTEN mutations ${ }^{28}$. Two unrelated patients had PTEN:c.407G>A mutation, in our study. This mutation has been reported pathogenic by four different reputable centers. In order to determine whether this variation has a founder effect in terms of PTEN gene mutations, it should be analyzed in larger groups.

RAD51 recombinase has a critical role in the repair of DNA double-strand breaks by homologous recombination. There are five RAD51 paralogs in humans; RAD51B, RAD51C, RAD51D, XRCC2, and $\mathrm{XRCC} 3$, and they promote the binding of RAD51 to the DNA ${ }^{29}$. Although mutations of these genes cause cancer in many tissues, they have also been reported in breast cancer. RAD51B:c.2T $>$ C has a start loss effect because the mutation occurred at the first codon. The variant was classified as VUS since the change was not previously reported and there were no functional studies of the effect of the mutation. Although the silico database is specified as damaging for the other missense VUS variation RAD51B:c.197C $>$ T, it has been detected at high frequency in a healthy population. Unlike these, RAD51C:c.907G $>$ T is a nonsense variation and nonsense variants were reported as diseasecausing for this gene. Since this variant is not found in ClinVar, HGMD, cancer databases, and literature review, RAD51C:c.907G $>$ T (p.Glu303Ter) is considered to be a novel variant. Although this mutation was found in the 7th exon of RAD51C, a 9-exon gene, RAD51C:c.955C > T in the same exon and RAD51C: c.994C $>\mathrm{T}$ in the 8th exon were also classified as pathogenic by HGMD.

Generally, germline mutations in the genes encoding succinate dehydrogenase (SDH) subunits result in hereditary pheochromocytomaparaganglioma syndrome, but there is also an increased risk for breast cancer ${ }^{30}$. Only one missense VUS variant (SDHC:c.424G>A) was described in SDH group genes. Although in silico database predicted this variant as damaging, there is no pathogenic missense variant, described with this gene.

\section{CONCLUSION}

It is vital to perform the hereditary cancer panel from index cases in families with high cancer incidence, whose BRCA1/2 negative and molecular background has not been elucidated, for preventive health policies. In addition, the identification of common familial cancer genes will guide personalized therapy planning.

\section{REFERENCES}

1. Momenimovahed $Z$, Salehiniya $H$. epidemiological characteristics of and risk factors for breast cancer in the world. Breast Cancer (Dove Med Press) 2019;11:151-164.

2. Shiovitz S, Korde LA. Genetics of breast cancer: a topic in evolution. Ann Oncol 2015;26:1291-9.

3. Shah R, Rosso K, Nathanson SD. Pathogenesis, prevention, diagnosis and treatment of breast cancer. World J Clin Oncol 2014;5:28398.

4. Buys SS, Sandbach JF, Gammon A, Patel G, Kidd J, Brown KL, et al. A study of over 35,000 women with breast cancer tested with a 25 -gene panel of hereditary cancer genes. Cancer 2017;123:1721-30.

5. Couch FJ, Shimelis H, Hu C, Hart SN, Polley EC, Na J, et al. Associations between cancer predisposition testing panel genes and breast cancer. JAMA Oncol 2017;3:1190-6.

6. Crawford B, Adams SB, Sittler T, van den Akker J, Chan S, Leitner O, et al. Multi-gene panel testing for hereditary cancer predisposition in unsolved high-risk breast and ovarian cancer patients. Breast Cancer Res Treat 2017;163:38390.

7. Karakasis K, Burnier JV, Bowering V, Oza AM, Lheureux S. Ovarian cancer and BRCA1/2 testing: opportunities to improve clinical care and disease prevention. Front Oncol 2016;6:119.

8. Daly MB, Axilbund JE, Buys S, Crawford B, Farrell CD, Friedman S, et al. Genetic/familial high-risk assessment: breast and ovarian. J Natl Compr Canc Netw 2010;8:562-94.

9. Risch HA, McLaughlin JR, Cole DE, Rosen B, Bradley L, Kwan E, et al. Prevalence and penetrance of germline BRCA1 and BRCA2 
mutations in a population series of 649 women with ovarian cancer. Am J Hum Genet 2001;68:700-10.

10. McKinnon PJ. ATM and ataxiatelangiectasia. EMBO Rep 2004;5:772-6.

11. Jerzak K, Mancuso T, Eisen A. Ataxiatelangiectasia gene (ATM) mutation heterozygosity in breast cancer: a narrative review. Curr Oncol 2018;25:e176-e80.

12. Decker B, Allen J, Luccarini C, Pooley KA, Shah M, Bolla MK, et al. Rare, proteintruncating variants in ATM, CHEK2 and PALB2, but not XRCC2, are associated with increased breast cancer risks. J Med Genet 2017;54:732-41.

13. Lowery MA, Wong W, Jordan EJ, Lee JW, Kemel Y, Vijai J, et al. Prospective evaluation of germline alterations in patients with exocrine pancreatic neoplasms. $J$ Natl Cancer Inst 2018;110:1067-74.

14. Eng L, Coutinho G, Nahas S, Yeo G, Tanouye R, Babaei M, et al. Nonclassical splicing mutations in the coding and noncoding regions of the ATM Gene: maximum entropy estimates of splice junction strengths. Hum Mutat 2004;23:6776.

15. Telatar M, Teraoka S, Wang Z, Chun HH, Liang $\mathrm{T}$, Castellvi-Bel $\mathrm{S}$, et al. Ataxiatelangiectasia: identification and detection of founder-effect mutations in the ATM gene in ethnic populations. Am J Hum Genet 1998;62:8697.

16. Yurgelun MB, Chenevix-Trench G, Lippman SM. Translating germline cancer risk into precision prevention. Cell 2017;168:566-70.

17. Stracker TH, Roig I, Knobel PA, Marjanovic M. The ATM signaling network in development and disease. Front Genet 2013;4:37.

18. Sandoval N, Platzer M, Rosenthal A, Dörk T, Bendix R, Skawran B, et al. Characterization of ATM gene mutations in 66 ataxia telangiectasia families. Hum Mol Genet 1999;8:69-79.

19. Weber-Lassalle N, Hauke J, Ramser J, Richters L, Gross E, Blümcke B, et al. BRIP1 lossof-function mutations confer high risk for familial ovarian cancer, but not familial breast cancer. Breast Cancer Res 2018;20:7.

20. Huzarski T, Cybulski C, Domagała W, Gronwald J, Byrski T, Szwiec M, et al. Pathology of breast cancer in women with constitutional CHEK2 mutations. Breast Cancer Res Treat 2005;90:187-9.
21. Fulk K, LaDuca H, Black MH, Qian D, Tian Y, Yussuf A, et al. Monoallelic MUTYH carrier status is not associated with increased breast cancer risk in a multigene panel cohort. Fam Cancer 2019;18:197-201.

22. Waltes R, Kalb R, Gatei M, Kijas AW, Stumm M, Sobeck A, et al. Human RAD50 deficiency in a Nijmegen breakage syndrome-like disorder. Am J Hum Genet 2009;84:605-16.

23. Uzunoglu H, Korak T, Ergul E, Uren N, Sazci A, Utkan NZ, et al. Association of the nibrin gene $(\mathrm{NBN})$ variants with breast cancer. Biomed Rep 2016;4:369-73.

24. Seemanová E, Jarolim P, Seeman P, Varon $\mathrm{R}$, Digweed M, Swift M, et al. Cancer risk of heterozygotes with the NBN founder mutation. J Natl Cancer Inst 2007;99:1875-80.

25. Antoniou AC, Casadei S, Heikkinen T, Barrowdale D, Pylkäs K, Roberts J, et al. Breastcancer risk in families with mutations in PALB2. N Engl J Med 2014;371:497-506.

26. Bodian DL, McCutcheon JN, Kothiyal P, Huddleston KC, Iyer RK, Vockley JG, et al. Germline variation in cancer-susceptibility genes in a healthy, ancestrally diverse cohort: implications for individual genome sequencing. PLoS One 2014;9:e94554.

27. Sy SM, Huen MS, Chen J. PALB2 is an integral component of the BRCA complex required for homologous recombination repair. Proc Natl Acad Sci U S A. 2009;106:7155-60.

28. Tan M-H, Mester JL, Ngeow J, Rybicki LA, Orloff MS, Eng C. Lifetime cancer risks in individuals with germline PTEN mutations. Clin Cancer Res 2012;18:400-7.

29. Stratton MR, Rahman N. The emerging landscape of breast cancer susceptibility. Nat Genet 2008;40:17-22.

30. Ni Y, Seballos S, Ganapathi S, Gurin D, Fletcher B, Ngeow J, et al. Germline and somatic SDHx alterations in apparently sporadic differentiated thyroid cancer. Endocr Relat Cancer 2015;22:121-30. 